\title{
The 'Reactive State' as Foreign Aid Giver: A Historical Analysis of the Aid Policy Regime (1953-1999) in South Korea
}

\author{
JISUN YI*
}

\begin{abstract}
Why are donor governments eager to increase foreign aid and how do they justify aid increases? This essay presents a historical insight into the bilateral donors' rhetoric behind aid expansion. South Korea provides one critical case. Not with standing its impressive aid growth over the last decade, the country has constantly failed to meet its annual commitment by a significant margin. This article argues that such policy behaviour might stem from its legacy as a 'reactive state.' During the Cold War, the country's nascent aid policy regime produced expansionary but non-strategic rhetoric, due to its fragmented structure and lack of indigenous policy rationales. Such traits of the policy regime linger today, thereby continuously favouring overestimated aid targets and outwardlooking aid initiatives.
\end{abstract}

Keywords: Reactive State, Foreign Aid, South Korea, Aid Rhetoric, Aid Expansion, Developmental State

* Ph.D. Candidate, King's College London, London, the UK;

E-mail: jisun.yi@kcl.ac.uk

DOI: 10.16934/isr.17.1.201606.55 


\section{INTRODUCTION}

Why are donor governments eager to increase foreign aid and how do they justify aid increases? This essay presents a historical insight into the bilateral donors' rhetoric behind aid expansion. As a country case, South Korea-which received foreign aid up to the late 1990s but has recently emerged as a donor with an impressive record - provides us with an interesting area of study for this central puzzle.

South Korea's transformation into a proactive aid giver invites interest among international scholars and aid practitioners. As one of the explanations for such a phenomenon, the notion of 'state entrepreneurship' comes to the fore: that is, South Korea might have not been so quickly expanding the scale and scope of global development cooperation without the distinctive role played by the government.

This 'state-directed aid growth' argument is a reflection of the East Asian 'developmental state' narrative, which captures the penetrating role of authoritarian governments in the region in effectively inducing industrialisation during the Cold War. It is widely believed that the tradition of having a strategic, competent state explains today's fast-growing South Korean official development assistance (ODA) (Söderberg 2010; Kim and Potter 2012; Kalinowski and Cho 2012; Sato and Simomura 2013).

Set against such mainstream perception, this study accommodates another historical point of view, arguing that the contemporary expansionary aid policies of the country might arise from its legacy as a 'reactive state.' The thesis of the reactive state serves as an analytical tool to reinterpret South Korea's expansionary aid policy as a by-product of domestic constraints and external influences.

Previously, the thesis of the reactive state (RS) was introduced to explain the foreign policy behaviour of non-hegemonic powers, which displayed a tendency to lack indigenous rationales for their foreign policy decisions. The thesis takes the approach of understanding the external behaviour of nation-states through looking at the internal structures and dynamics of their domestic policy regimes.

In other words, the RS thesis examines the endogenous sources of a state's particular foreign policy behaviour where reaction prevails over strategy. Distinguished from other types of states (i.e. proactive-hegemonic, middle-ranged, inflexible, and autistic states), reactive states are defined as having neither a strategic intent of policymaking nor a record of implementing such policies successfully, due to structural constraints.

Existing cases of reactive states-Japan, Norway, and Austria in the Cold War period-run parallel with contemporary South Korea, whose foreign aid policy choices are in favour of budgetary expansion in aid giving, but whose policy initiatives tend to be outward-looking and lacking in strategies and domestic support. Likewise, South Korea constitutes a critical case, given its historical 
record of expansionary aid rhetoric. This country case allows us to explore which historical-institutional elements of its aid policy regime might explain not only the process of transformation - from a post-war, poverty-stricken aid recipient to an DAC ${ }^{1}$-recognised aid donor-but also the pace of aid growth-i.e. from 2006 to 2014, when its official development assistance (ODA) increased fourfold, while the total ODA from all DAC donors grew only 1.2 times.

\section{Why are DAC's Asian Donors Overambitious?}

In the OECD-DAC community, there is a unique feature observed for two Asian member countries' aid provisions. Unlike European and American member states, both Japan and South Korea show distinctive gaps between annual aid commitments and actual disbursements (Table 1). If we single out the South Korean case, that has shown one of the most marked aid scale-ups across the DAC from the 2000s onwards, and the country's ODA policies persistently entail overestimated aid targets according to the OECD ODA records.

TABLE 1. ANNUAL RATIOS OF BILATERAL ODA COMMITMENT (100.0) TO DISBURSEMENT (LISTED IN THE TABLE): WESTERN VS. EAST ASIAN DAC MEMBERS (2000-2013) (UNIT: \%)

\begin{tabular}{ccccc}
\hline & DAC countries & DAC-EU members & Japan & South Korea \\
\hline 2013 & 89.9 & 101.0 & 47.0 & 66.3 \\
\hline 2012 & 88.5 & 92.3 & 49.4 & 69.6 \\
\hline 2011 & 89.8 & 98.2 & 54.6 & 68.9 \\
\hline 2010 & 84.7 & 93.6 & 50.7 & 58.8 \\
\hline 2009 & 81.2 & 85.8 & 52.0 & 41.2 \\
\hline 2008 & 77.8 & 86.1 & 46.2 & 48.1 \\
\hline 2007 & 83.8 & 90.1 & 53.4 & 50.4 \\
\hline 2006 & 79.7 & 79.0 & 64.4 & 51.0 \\
\hline 2005 & 87.7 & 90.1 & 67.5 & 97.5 \\
\hline 2004 & 80.5 & 90.0 & 57.4 & 54.2 \\
\hline 2003 & 77.5 & 88.9 & 50.5 & 83.7 \\
\hline 2002 & 88.7 & 87.3 & 86.7 & 75.6 \\
\hline 2001 & 85.7 & 90.4 & 69.4 & 100.8 \\
\hline 2000 & 86.3 & 93.1 & 78.9 & 65.3 \\
\hline SOURCE: Anh & com & & & \\
\hline
\end{tabular}

SOURCE: Author's computation based on QWIDS (accessed on 15 March 2015).

Apart from the overambitious goal-setting pattern, South Korea's aid growth per se is far from mediocre. From 2000 to 2014, South Korea's ODA grew 8.7 times, whereas the total ODA volume of the DAC increased 2.5 times in the same period. In the post-global financial crisis period (2009-2014), South Korea stayed 
top-ranked in terms of aid growth rates (228\%) while the crisis-affected DAC community, by and large, showed sluggish aid increases (114\%) (OECD 2015).

This quantitative expansion, however, appears to accompany few noteworthy shifts in its aid makeup and regional/sectoral orientations. Throughout the years from 2000 to 2014, annually, an average $75 \%$ of ODA was given bilaterally. Although Asia (52.9\% in 2014) always received the largest portion of South Korean ODA, Africa has gradually emerged as the second largest aid-receiving region $(23.8 \%$ in 2014) since 2006 . South Korean ODA has constantly been disbursed mostly in the area of social infrastructure and services (40.7\% in 2014) -apart from other sectors of economic infrastructure (34.2\%), production (10.8\%), and the rest (14.4\%). Neither does DAC membership for South Korea (2010) seem to result in a significant change to its aid content; it might work as a factor for the continued aid increase.

Bilateral donors' half-met policy rhetoric does cause concern. Such behaviour on the part of a donor is argued to work against making ODA predictable, so that aid recipients are highly likely to experience difficulties in planning their aid management (Lensink and Morrissey 2000; Bulir and Hamann 2008; Kangoye 2013). According to a recent OECD report, South Korea's medium-term aid predictability accounts for $46 \%$, which is considered far lower than the average of the DAC (OECD 2015). As part of responding to the problem of unmet aid commitments, the South Korean government recently moderated its aid target (0.2 ODA/ $\mathrm{GNI}^{2}$ by 2020; initially set at 0.25 by 2015) when releasing its second "Basic Plan for International Development Cooperation (2016-2020)" in 2015.

As posited in this essay, such overambitious ODA policies of donor governments might be seen as not simply a miscalculation or wishful thinking on the part of aid policy makers. Given that donors' aid policy behaviour can be a manifestation of donor government's underlying aid politics, this article raises two interlinked questions: First, under what policy-formulating contexts are governments motivated to increase their overseas aid disbursements? And second, to what extent does history — in this case, a previous foreign aid policy regime — offer an explanation for the phenomenon?

\section{Understanding Bilateral Donors'Rhetoric about Aid Expansion}

Aid transfer from advanced to less developed countries is considered sensitive to various international and domestic factors surrounding both donor and recipient countries. However, as proven in existing cross-country studies, bilateral donors' aid calculations and actual disbursements are determined more by their political and strategic considerations, and less by the needs and conditions of the aid recipient governments (Hook et al. 1998; Alesina and Dollar 2000).

Traditionally, bilateral donors' behaviour is understood from the perspective 
of 'motives.' In the international politics literature, foreign aid policies and patterns (e.g. aid volume, regional allocation, aid type, conditionality) are largely explained by donor's multiple set of motivations (Morgenthau 1962). Existing typologies of aid motivation bifurcate between the self-interests of the donor state and humanitarian/altruistic objectives.

According to this approach, an increase in a donor country's aid disbursement is translated into a strengthened strategic championship of a particular aid motive. In the same way, aid rhetoric is considered a political output that results from a tension between the realist and liberal internationalist traditions of donor states. Through foreign aid provisions, donor states are expected to achieve the two contending tasks of pursuing benefits for their own citizens and fulfilling international moral obligations as better-off economies. Therefore, a gap between international commitments and actual practices is created.

Given that decision-makers' public rhetoric often turns out to be instrumental, the motive dimension has a clear limitation as a way to tap into the origins of the inconsistency between motive and actual policy behaviour. Therefore, an alternative dimension emerges, shedding light on the structures and dynamics of the domestic policy regime as the key explanatory factor in the donor behaviour of setting aid targets and justifying aid expansion. For instance, Breuning (1995) examines aid policy behaviour through decision-makers' perceptions and policymaking structures. His content analysis of parliamentary debates (1975-1991) reveals that while the United Kingdom and the Netherlands showed a fair alignment between aid commitments and actual disbursements, Belgium displayed a distinctive incongruence between aid rhetoric and behaviour, mainly due to its peculiar political structure in which aid policy did not have a stand-alone policy realm.

Apart from the conventional aid rhetoric literature, the reactive state thesis has also functioned as an approach to aid policy behaviour in non-western settings. Reflecting on Japan's foreign policy initiatives on quantitative and qualitative expansion of ODA during the Cold War era, Hook and Zhang (1998) contend that a rivalry between two lead ministries in its aid policy regime was in large part accountable for not only a dualistic policy discourse, but also a chronic gap between aid commitments and actual disbursements.

Nonetheless, the existing research on aid rhetoric has yet to explore a wider context. Although the earlier studies provide us with useful analytical frames and ideas, the previous debates draw insufficient attention to the historical roots and traditions that can also explain aid policy behaviour. Traditions are highly relevant if we are talking about time-honoured institutions such as perceptions or structures that affect aid policymaking. Also, this essay argues that new donor cases are largely absent in this aid rhetoric and aid behaviour debate. In this intellectual vacuum, this qualitative case study aims to add insight and evidence from the South Korean case to the existing literature. 


\section{Research Strategy}

This study aims to understand aid rhetoric by highlighting the institutional arrangements of the donor's policy regime. As a critical case, South Korea's inceptive aid policy regime from the 1950s to the 1990s is examined. Due to a significant lack of quantitative datasets in this area of study, a qualitative method is adopted to narrow down the data gap. Relevant data are collected from a comprehensive range of state documents (that are available at ministerial and subordinate agencies) and existing academic works.

In the following section, the 'strategic state' approach, as the dominant view in understanding South Korea's expansionary aid policy, is challenged. To counterbalance the existing view, the RS thesis is advanced. Adopting a framework that RS scholars previously introduced, historical developments-before the consolidation of contemporary South Korean foreign aid policy regime - are captured in terms of (i) key policy actors, (ii) aid policy-making structures, (iii) political communication between aid regime and preferences at domestic and international levels, and (iv) prevailing policy discourses.

\section{REVISITING FOREIGN POLICY TRADITIONS IN EAST ASIA}

In fact, the role of the state is regarded as a sine qua non dimension to understand a country's aid policy behaviour and performance. In a way, South Korea's expansionary aid policy from the 2000s onwards is understood by revisiting the tradition of East Asian developmental states.

In fact, the 'developmental state' (DS) concept has been discussed in the worldwide context of how determination and capacity of nation-states have contributed to achieving their national goals of poverty reduction and economic growth (Woo-cumings 1999; Evans 2010). But the concept has been substantially developed through the East Asian cases, including the first Asian industrialiser, Japan, and the newly industrialising economies in the Cold War era-South Korea, Taiwan, and the city-states of Hong Kong and Singapore. It is widely acknowledged that these economies promoted a third type of capitalism, in which the idiosyncratic intervention of the state was credited for the rapid economic growth and industrialisation during the Cold War (WB 1993; Woo-Cumings 1999).

Among DS scholars, major academic contributions are made on state institutions that possibly steered the governments in favour of an unconventional set of international and domestic policies. In particular, to explain the proactive policy behaviour of East Asian industrialisers, the following state institutions are considered: competent/autonomous bureaucrats, strong political leadership, centralised governance, and state-business coalitions.

Johnson (1995) argues that highly competent, autonomous policy elites in the 
government are central to the Japanese developmental state model, and visible throughout its process of post-war reconstruction and economic growth. On the other hand, Kohli $(1999 ; 2004)$ counter-argues that authoritarian/enlightened leadership - that might have exerted a centralised control over an inherently fragmented bureaucratic system of public governance-is essential for the success of a developmental state, drawing upon comparative evidence from two political regimes, Rhee Sygnman (1945-1960) and Park Chung-hee (1963-1979), in South Korea. Another group of scholars finds that the true nature of DS rests on a close collaboration between state and business (Evans 1995; Herring 1999). In particular, the state's credit-based control over domestic businesses created an effective developmental coalition between state and society (Woo 1991; Woo-Cumings 1999).

In parallel with this established understanding of the DS institutions that might determine a country's policy choices and behaviour, similar attention is given to a particular role of the government in ODA practices. In line with the historical DS argument, there has been a growing debate on how the legacies of the 'developmental state' are manifested in the contemporary foreign/development policy arena for East Asian donors. A group of scholars observed that the remarkable ODA growth observed throughout East Asian donors, for instance, might be the 'intended' outcomes of having 'strategic governments', despite significant changes in the domestic and international contexts (Söderberg 2010; Kim and Potter 2012). The role of political leadership and state bureaucrats - those who are inspired to enhance the global status of South Korea by promoting various ODA activities - is articulated as a dominant, systematic force for aid increases and development initiatives (Kalinowski and Cho 2012).

However, although the tradition of a developmental state constitutes a critical explanatory factor for a rapid rise of South Korean donorship, such historical reflection also has limitations. These limitations arise when we pose the particular question of why South Korea tends to make ambitious ODA increase pledges but often fails to meet its annual commitments. Regarding such non-strategic policy behaviour, the 'developmental state' discussion offers limited clues to understanding the nature and origins of the donor government's aid rhetoric.

Refocusing on what kind of state resources, state-society relationships, and bureaucratic incentives might have been involved in the policy process in the early years of ODA provision, this essay suggests that previous debates on the 'reactive state' provide us with more relevant points for thought.

The thesis of the 'reactive state' initially embodies an explanation of the postSecond World War Japanese foreign policy stance regarding how Japan utilised an increasing volume of ODA as a supplementary apparatus to support its USdependent diplomacy. Such an interpretation came as a revisionist insight in the 1980s and 1990s, since many still saw Japan as a 'proactive' actor through its ever-growing foreign aid contribution. In a wider sense, this concept is applicable 
to other bilateral donors whose governments fail to undertake independent policies and are sensitive to outside pressures (Calder 1988). In particular, the existing debate on the Japanese 'reactive state' has great implications for interpreting South Korean aid policy behaviour in regard to its rhetoric on ODA expansion.

\section{The Thesis of the Reactive State (RS): A Missing Narrative}

Reactive states are defined as displaying outward behaviour that is characterised by two aspects (Calder 1988, 519): one is the case where a state fails to make independent foreign policy decisions despite its capacity to do otherwise; the other is where a country alters its course of action under external pressures. A 'reactive state' is distinguishable from other types of state- such as hegemonic powers, which tend to exert leadership in global affairs; or isolated/incapable states, which have neither the willingness nor the capacity to respond to external pressures.

Western examples of reactive states include small, high-income European economies - such as Finland, Austria, and Norway. These countries' foreign policy decisions are considered relatively susceptible to the global political and economic climate, due to their heavy dependence on the markets in hegemonic power countries. In a similar sense, South Korea, Taiwan, and Singapore - those who have been export-dependent economies - traditionally fall into the category of reactive states.

\section{Implications of the Japanese Reactive State}

Japan has been the epicentre of the 'reactive state' debate. Relevant discussions are made at two interrelated levels: Both gaiatsu ${ }^{3}$ (foreign pressure) and domestic policy-making politics are examined as integral factors to the formation and transformation of Japanese foreign aid policy behaviour (Orr 1990; Yasutomo 1995; Miyashita 1999).

Post-war Japan - as the then-emerging donor from the 1950s until its unprecedented aid culmination in the mid-1990s - is comparable with the South Korean case in terms of US alliance and contentious bureaucratic tradition. Despite that Japanese and South Korean DS models might have been socially embedded to significantly varied extents (Hwang and Lim 2003), economism - the ideology that the growth of the national economy is prioritised over other national agendas -was firmly predominant in these newly industrialising economies, perhaps shaping similar characteristics of state decision-making structures and political dynamics.

In particular, the politics of foreign aid takes place in a different way compared to that of traditional donor societies. For new donors, foreign aid giving, as a low-profile policy issue, might not be favourably understood domestically. 
Simultaneously, it can be recognised by policy-makers as an opportunistic imperative of a country that can enhance its political and economic status at the global level. Given such contradictory pressures on aid giving, RS scholars contend that this expectation gap might give rise to a particular policy culture among policy makers. In this respect, the Japanese case and its historical evidence are relevant to the contemporary contexts and behaviour of late-arriving East Asian aid givers, including South Korea.

\section{Key Propositions for Analysing Aid Policy Regimes: Actor, Structure, Influence,} and Ideology

Accumulated research on the 'Japanese reactive state' sheds light on the following state institutions: (i) key actors, (ii) features of the policy-making structure, (iii) policy communication within the administration and between government and society, and (iv) the main themes of the aid policy discourse. As key loci of the reactive state model, these state institutions are collectively useful to reconstruct a contextual understanding of the policy climates that policy-makers encountered and engaged. Also, these institutional foci constitute competing explanations for the reactive foreign policy behaviour of Japan.

\section{(1) Actor}

In post-war Japan, foreign aid policy was set by a fast-learning but changeresistant group of state bureaucrats (Inoguchi 1989). The nature of the aid bureaucracy is often referred to as a source of Japanese reactiveness (or 'passivity') in its foreign policy decisions. Also, Rix (1990) points out that there were no unified domestic political lobby groups in the realm of foreign aid. Therefore, state bureaucrats predominated in the aid policy formation process, so that Japanese aid policy behaviour is, in large part, reflective of the nature of these aid policy elites.

\section{(2) Structure}

The structure of the aid policy regime was also taken into account in regard to why the Japanese government had inherent difficulties in formulating coherent aid strategies and policies. Potter and Sueo (2003) argue that Japan was structurally incapable of making sustained, innovative foreign policies because of political and economic immobility at home. This immobility appeared as sluggish policy decision-making traditions within the Japanese administration.

The issue of ODA often suffered from bureaucratic conflicts. In the foreign aid policy domain, a four-ministry system - the Ministry of Foreign Affairs (MFA), the Ministry of International Trade and Industry (MITI), the Ministry of Finance 
(MOF), and the Economic Planning Agency (EPA) — had all been at work until the 1990s. Under the pluralistic ODA regime, Japan fostered two separate aid policy communities: one was the MOF/MITI-led aid policy network (in which concessional loan projects were managed); and the other was MFA-led (Katada 2002). As Calder pointed out, there was strong sectionalism between the two groups of aid bureaucrats, who liked to extend their own nawabari. ${ }^{4}$ This bureaucratic struggle was seen to negatively affect the formation and entrenchment of common aid strategies and a consensual aid philosophy throughout the aid policy regime.

\section{(3) Influence}

Influence here refers to the direct or indirect impacts of domestic and international preferences on the government's strategy-building and policy-making processes. In stark contrast to a close collaboration between state and business in the industrial policy domain, most aid policy issues were seriously underrepresented in the Japanese policy system (Rix 1990, 464). Japan's aid to China and Russia were the examples that supported the RS thesis. These proposed aid activities were controversial domestically but carried out upon the US's assent (Miyashita 1999; Miyashita and Sato 2001). The American gaiatsu served as the major source of legitimacy for policy-makers when newly disbursing or increasing ODA. In particular, the MFA strategically used the American reference in order to expand its clout against economic bureaucrats, since the MFA had no strong domestic constituency that could buttress its ODA policy stance (Orr 1990).

\section{(4) Ideology}

'Karaoke diplomacy' is a term that describes Japanese traditional foreign policy style - a tendency for Tokyo to align its policy stance with the Washington doctrine, but leave specific choices for policy delivery to Japan (Inoguchi and Jain 2011). Also, another crucial feature of Japanese aid policy from the 1960s to the 1980s was that the government introduced a series of grandiose plans for aid expansion in quantitative terms, but few qualitative changes in aid practices had been observed throughout the period of ODA growth. This is presumably because the Japanese aid policy-makers championed the notion of 'more aid is better' until this idea was severely challenged by domestic interest groups in the face of the economic downturn (Katada 2002, 341).

\section{HISTORICAL ANALYSIS OF THE AID POLICY REGIME IN SOUTH KOREA}

Prior to offering a close observation on the South Korean foreign aid policy 
regime in its nascent form, South Korea's mixed experience as an aid recipient and development partner should be examined. This historical context highlights the earlier developments that led to the creation and evolution of a foreign aid policy regime. Along with the existing view on the South Korean state's autonomous use of foreign aid for national economic growth, the following observations present evidence of the state's external reactivity that existed in the period of aid receipt and the very early years of development partnership.

\section{Aid-Receiving Period (1950s-1990s)}

\section{(1) Funnelling Foreign Aid to Post-War Reconstruction and Industrial Transformation}

Arguably, post-war South Korea (from 1953 onwards) depended heavily on foreign resources for its long-term transformation to an aid-independent economy (Lim 1985; Woo 1991). From 1945 to 1999, an estimated USD 12.7 billion was funnelled into South Korea in mixed forms of bilateral aid, multilateral lending, and humanitarian assistance (Kim 2011). During the period of aid receipts, 92.7\% of aggregate aid inflow was given bilaterally-mostly from the US (USD 5.5 billion) and Japan (USD 5.0 billion). The ratio of loans to grants stands at almost one-to-one throughout the entire period, whereas the major type of foreign aid that South Korea was given had gradually shifted from grants to non-grants.

\section{(2) Aid Management as an Aid Recipient}

In the aftermath of the Korean War (1950-1953), South Korea benefited from a huge aid influx, exclusively from the US, since the country was considered a strategic breakwater to contain communist influence. Under the pro-American Rhee Syngman administration (1948-1960), foreign assistance served as the primary income source and political stabilizer (Woo 1991). In the pre-war period, South Korea-destined US assistance was exclusively delivered by the US Economic Cooperation Agency (ECA) - which opened a branch office in Seoul and exerted great leverage over the process of national development, strategy building, and policy implementation.

Shortly after the Korean War, the Combined Economic Board (CEB) - a USled joint aid-coordinating body that was composed of bilateral donors and UN aid organisations - soon replaced the ECA. Although this change would have led to a favourable environment for South Korea to be less dependent on American resources, the Rhee administration remained in a close consultation with the US's aid officials. After the Park Chung-hee regime took power (1961-1979), the main components of aid inflows had been gradually shifted from humanitarian support 
to concessional loans.

In anticipation of forthcoming decreases in US aid-which were scheduled in tandem with the revised US foreign policy stance under the Kennedy administration, the Park regime struggled to secure other possible foreign resources to minimise domestic shocks and to continuously stimulate the national economy. After South Korea reached a war reparations deal ${ }^{5}$ with Japan in 1962, Japan turned into the largest bilateral aid provider, channelling concessional loans and technological transfers to the South Korean economy.

In the Cold War milieu, in which two Koreas furiously competed for international legitimacy, the Park regime was not free from American interference. This was due to Seoul's dependence on the US in terms of national security and markets. Throughout the Park regime, US aid played a crucial role in national economic development. South Korea was the third largest recipient of US aid, after Vietnam and Israel, from 1946 to 1980, according to USAID. ${ }^{6}$ Although Park's first five-year development plan (1962-1966) was directed at making its economy self-sufficient, the government did not underestimate the fact that South Korea was still highly aid-dependent, and foreign aid was managed under the penetrating monitoring of the USAID (Woo 1999).

With regard to the governmental structures and mechanisms of aid management under the Park administration, the Economic Planning Board (EPB), after the disbanded $\mathrm{CEB}$, performed as a central agency to attract and manage foreign loans (Kim 2011). Internally, the EPB was a super-agency that enjoyed a high level of autonomy, with the exclusive support from the president, who was well aware of the great importance of securing and channelling foreign loans for national development. Despite weakened US influence, the EPB maintained its favourable working relationships with the US and other international aid organisations.

\section{Development Partnership (1960s-1990s):}

\section{(1) Occasional Provisions of Technical Assistance from the 1960s-1980s}

The very first development cooperation activity of South Korea was dated 1963 in the records. Since then, its USAID-funded and self-funded development cooperation activities have occasionally been organised in the form of technical cooperation. This has largely involved dispatches of South Korean experts to other developing countries and invitation of foreign government officials to South Korea for professional training. This small-scale technical cooperation with the rest of the developing world remained insignificant until the late 1980s. During this period, South Korea itself received a staggering amount of foreign assistance from the rest of the world.

Notwithstanding the meager scale of development partnership, the early 
South Korean aid programme was determined by its relationship with the North (Kim and Seddon 2005). The targeted partner countries were the newly independent countries of Africa and Latin America. It was part of Park's foreign policy strategy to promote development partnerships with these remote countries against the expanding influence of North Korea through the Non-Aligned Movement. ${ }^{7}$ Even under subsequent regimes, foreign aid was disbursed mainly according to the identical diplomatic purpose, as clearly laid out in the official statement ${ }^{8}$ of the Ministry of Foreign Affairs (MOFA).

\section{TABLE 2. EARLY YEARS OF SOUTH KOREAN DEVELOPMENT PARTNERSHIP}

\begin{tabular}{cl}
\hline & \multicolumn{1}{c}{ Development cooperation activities } \\
\hline \multirow{2}{*}{$1960 \mathrm{~s}$} & $\begin{array}{l}\text { First training project for foreign trainees (funded by USAID) (1963) } \\
\text { Government-funded training project initiated (1965) } \\
\text { Medical and Korean martial arts expert dispatch (1968) }\end{array}$ \\
\hline \multirow{2}{*}{$1970 \mathrm{~s}$} & $\begin{array}{l}\text { In-donor training projects for foreign technicians (1975) } \\
\text { First bilateral grant programme initiated by the Ministry of Foreign Affairs (1977) }\end{array}$ \\
\hline \multirow{2}{*}{ 1980s } & $\begin{array}{l}\text { International Development Exchange Program launched by the Korea Development } \\
\text { Institute (1982) } \\
\text { Technical cooperation activities initiated by the Ministry of Construction, the Ministry } \\
\text { of Labour, and the Ministry of Science and Technology (1983, 1984, 1987) }\end{array}$ \\
\hline UNESCO Korean Young Volunteer project launched (1989)
\end{tabular}

SOURCE: www.koica.go.kr.

\section{(2) New Aid Momentum in the 1990s}

From the late 1980s, South Korea's economic growth led to substantial international pressure for the country to address its moral obligation as a better-off economy towards the less developed world. In a way, a burden-sharing initiative between advanced economies and newly industrialising economies (NIEs) officially emerged at the 1987 Louvre Accord in Paris. Set against the growing international demand of the NIEs, the South Korean government started to plan its annual aid commitment and established two specialised aid agencies- the Economic Development Cooperation Fund (EDCF) in 1987 and the Korea International Cooperation Agency (KOICA) in 1991.

Throughout this internal process of launching new, full-scale aid projects, the Japanese aid model was the major reference point for the South Korean policymakers. It appears as a strategic choice of the government to emulate the Japanese aid policies and structures in consideration of shared interests of being highly trade-dependent economies and holding a strategic relationship with the US.

During the period of institutional build-up, South Korean ODA systems gradually embraced economic and commercial interests in Asia. However, due to extremely limited domestic resources and insufficient capacity of aid administration, South Korean aid policies remained proactive throughout the 1990s. Overall, in the previous aid regime, the sources for aid increases in South Korean ODA were 
largely supplied from the outside rather than from domestic, endogenous demands.

TABLE 3. SOUTH KOREA's ECONOMIC EXPANSION AND AID SCALE-UP IN THE 1990S

\begin{tabular}{cccccccccc}
\hline & 1991 & 1992 & 1993 & 1994 & 1995 & 1996 & 1997 & 1998 & 1999 \\
\hline $\begin{array}{c}\text { ODA } \\
\text { (USD million) }\end{array}$ & 57.5 & 76.8 & 111.6 & 140.2 & 116.0 & 159.2 & 185.6 & 182.7 & 317.5 \\
\hline $\begin{array}{c}\text { ODA/GNP ratio } \\
\text { (Per cent) }\end{array}$ & 0.020 & 0.025 & 0.034 & 0.037 & 0.026 & 0.033 & 0.042 & 0.058 & 0.079 \\
\hline $\begin{array}{c}\text { GNP } \\
\text { (USD billion) }\end{array}$ & 292.0 & 305.7 & 330.8 & 378.0 & 452.6 & 480.4 & 437.4 & 316.8 & 402.1 \\
\hline $\begin{array}{c}\text { Bilateral ratio } \\
\text { (Per cent) }\end{array}$ & 54.7 & 58.8 & 53.8 & 42.8 & 61.8 & 77.4 & 59.9 & 68.2 & 41.3 \\
\hline $\begin{array}{c}\text { Grant ratio } \\
\text { (Per cent) }\end{array}$ & 53.6 & 50.8 & 38.5 & 36.7 & 55.9 & 52.4 & 45.2 & 38.8 & 33.6 \\
\hline
\end{tabular}

SOURCE: Author's compilation based on OECD QWIDS.

\section{(3) Other Aid Factors to be Considered}

Both the abrupt dissolution of the Soviet Union and the UN's recognition of the two Koreas in the early 1990s provided a long-term momentum for change in South Korean aid giving. However, South Korea's first emergency relief to North Korea in 1996 and the Asian financial crisis in 1997 do not appear to have interrupted a long-term upward trend in ODA. This is partially because North Korea-destined emergency aid from the South does not count as ODA due to constitutional interpretations, and these humanitarian activities were organised exclusively by the Ministry of Unification.

\section{The Aid Policy Regime in the Cold War Era}

Previously, the historical contexts that the South Korean government encountered from the 1950s throughout the 1990s assisted our better understanding of the country's mixed, unique experience of aid receipt and development partnership. The US alliance, the diplomatic competition with North Korea, and the Japanese aid model were identified as solid factors that shaped South Korea's aid giving motives during the Cold War.

The following focused analysis of the aid policy-making regime articulates that from the early years of aid provision, aid policies and strategies were made in a 'reactive' manner. As the RS thesis predicts, the reactive nature of foreign policy behaviour does include the state's policies that are neither strategically driven nor socially embedded. Therefore, this article posits that expansionary aid policies, for instance, cannot be automatically considered those of a 'proactive' state unless we look at state's systems of aid policy formation and its internal policy discourse.

Another important point for thought rests on what fundamentally makes reactive states for bilateral aid donors. As RS scholars are primarily interested in 
whether a donor government constitutes a reactive state by choice or by nature (Miyashita 1999, 727), it is interesting to see where the South Korean case might be placed. In other words, the question is whether a donor government strategically chooses reactive policy behaviour despite its full capacity to do otherwise; or whether it is domestic constraints (e.g. the absence of consensual aid objectives or integrated aid systems) that make it difficult to produce proactive and independent aid policies; or whether the government culturally prefers to set aid targets high or exclude domestic interests in its policy-making process.

\section{(1) Receptive Aid Bureaucracy}

Traditionally, the president of South Korea exerts penetrating leverage over both domestic and international policy areas (Hahm and Plein 1995). During the Cold War, Seoul's diplomacy was centred on national security, due to the interKorean military tension. But post-Cold War foreign policy was transformed to address the issues of globalisation by expanding economic cooperation with the rest of the world. The more foreign affairs issues are broadened, the more technical issues, as opposed to high-profile/traditional foreign affair agendas, come under the auspices of state bureaucrats.

Foreign aid policy hardly attracts the keen interest of the president or the political parties in South Korea. In particular, the traditional South Korea development model was profoundly growth-oriented, whereas redistributive policy discourses were marginalised among political leaderships and policy-makers. Given that, foreign aid giving was limitedly legitimised only because Korea itself benefited from foreign help.

A 'not-losing-face' rationale was well shared among the state bureaucracy in the early stage of foreign aid provision (1960s-1980s). However, while the government went through the process of dismantling its traditional structure in the face of globalisation, state bureaucrats became significantly divided and competitive in the foreign aid discourse. During this period, state bureaucrats increasingly accepted the neo-liberal notion of capitalism, favouring price stability over growth, and championed reduced state intervention. The US-educated economist, Jae-ik Kim, the former Director-General of the EPB (1976-1980) and the Senior Secretary to the President for Economic Policy (1980-1983), was an example of this new change within the South Korean government and state economic bureaucracy (Evans 1995). Indeed, such forces shaped the international economic policy fields, including aid policy.

\section{(2) Fragmented Aid Policy-Making Structure}

The defunct Economic Planning Board (EPB) — which had been independently 
empowered to design five-year national economic development plans and to monitor policy implementation from 1963 to 1994-was the single planner, co-ordinator, and budgeting body for all ODA affairs. Before the 1990s, other ministries - the Ministry of Science and Technology, the Ministry of Labour, and the Ministry of Construction and Transport-were also collective aid distributors. They provided small-scale technical assistance on an ad hoc basis. Until the late 1980s, none of these ministries developed their leadership or specialisation in the ODA policy field.

As a critical juncture, the establishment of the ODA-specialised agencies, the EDCF and the KOICA, eventually strengthened the legitimacy of the Ministry of Foreign Affairs and Trade (MOFAT) ${ }^{9}$ and the Ministry of Finance and Economy $(\mathrm{MFE})^{10}$ to take the lead in the ODA policy sphere. Thereafter, once the single aid manager, the EPB, was phased out by a structural reform that aimed at making a smaller, more efficient government, these newly established institutional arrangements gave rise to the dualistic power structure of contemporary aid administration. Since then, the South Korean aid administration evolved into a distinctive structure that is favourable to achieve high efficiency in aid expansion but not in producing coordinated, coherent aid policy strategies and consensuses within the aid administration.

The historical relationship between MOFAT and MFE - the two leading ministries in the ODA policy in the 1990s - was one of rivalry. As Seoul's determination to win the diplomatic competition with North Korea weakened in the post-Cold War period, the role of MOFAT became tarnished. While MOFAT attempted to strengthen its presence, MFE emerged as a balancing power in the national ODA policy-making arena (Kim 2011). Whereas MOFAT stressed the political and diplomatic objectives of aid giving over humanitarian and economic goals, the MFE placed emphasis on measurable economic returns on ODA spending. Particularly, the economic bureaucrats articulated the positive functions of loans, referring to South Korea's own experience of effectively utilising concessional loans for national economic growth.

\section{(3) Foreign Influences over Aid Policy Formation}

When it comes to the degree and nature of state-society embeddedness in the aid policy-making process, the Japanese and South Korean aid models might appear different. From the beginning of the Japanese ODA provision, the state-business coalition (i.e. the $\mathrm{MOF} / \mathrm{MITI} / \mathrm{business} \operatorname{triad}^{11}$ ) provided the strongest legitimacy and momentum for aid expansion in support of the private sector's commercial opportunities overseas (Orr 1990; Katada 2002). On the contrary, the South Korean model rarely experienced any significant levels of domestic interests or pressures in its aid policy arena. The corporatist nature of the South Korean developmental 
state appeared very weak in this foreign development cooperation policy field. For MOFAT, which normally earned little domestic support for its policy stance, foreign aid could be a double-edged sword: the foreign affairs ministry enjoyed a great deal of autonomy over its management of aid, avoiding potential public criticism or public scrutiny, but it had no firm political capital to support its aid operations.

This 'socially-exclusive' aid model of South Korea led it to turn to external influences, as a consequence. In the 1990s, there was a tendency in MOFAT, in an attempt to expand grants to newly diplomatised Asian countries, to find most of legitimacy and references in the US and international organisations.

\section{(4) Pluralistic, Reactive Policy Discourse for Aid Giving and Aid Expansion}

The nascent ODA policies of South Korea arose in the Cold War context. At the same time, security concerns associated with North Korea predominated in this sub-field of foreign policy. This view is supported by the geographical allocation of the early days of the South Korean ODA, which remained concentrated in Africa and Latin America.

Although the government's posture in scaling up and systematising ODA outflows rarely appeared persistent in the 1990s, aid-managing ministries and agencies started to articulate the purposes and functions of ODA in more diverse ways. With the neo-liberal movement sweeping the country, aid policy discourse within the administration embraced pragmatic, commercial notions. In this regard, foreign aid was increasingly seen as a vehicle for stimulating overseas investment. For instance, under the effect of the Asian financial crisis, concessional loans won legitimacy over grants. This gradual change is also supported by the fact that South Korea was a strong student of the commercially oriented Japanese ODA model (Kim and Seddon 2005).

Regarding ODA goal/agenda setting, aid-managing ministries turn out to be traditionally overambitious in their aid planning. In 1990, EPB officials released their mid-term plan to increase ODA to a level that was equivalent to $0.2 \%$ of GNP - the ODA/GNP ratio stood at 0.02 in 1990 as shown in Table 3-, simply referring to the then-average level of OECD/DAC countries. MOFAT, in 1999, set a target of $0.1 \%$ ODA/GNP, with no specific timetable attached. A primary rationale behind the target was MOFAT's rule-of-thumb in its aspiration to gain international recognition for South Korea's economic and political status (Kim and Seddon 2005). None of these targets was realistically driven at that time - more than a decade later, South Korea's highest ODA/GNI reached at $0.14 \%$ in 2012 . To find a proper level of aid commitment, a few internal discussions took place across the ministries. Unlike the Japanese ODA policy regime, where the MFA takes the leadership in providing the overall aid strategies and coordinating tasks, the South Korean counterpart lacked policy coordination mechanisms. 


\section{CONCLUSION}

As an approach that aims to understand the external behaviour of nonhegemonic states through their internal arrangements of foreign policy regimes, the thesis of the reactive state serves as a new prism for the South Korean case.

As proposed by the 'strategic state' notion, the South Korean government's 'developmental state' legacy might allow the country to be put on the fast track to becoming a recognised donor. However, this RS analysis counter-argues that South Korea's expansionary aid policy is, rather, the by-product of external influences and structural constraints that lie within the foreign aid policy regime. Under the historical contexts of the South Korea-US alliance, diplomatic competition between the two Koreas, and adherence to the Japanese aid model, foreign aid was utilised as a new but passive policy tool for Cold War diplomacy. A fragmented aid policy regime produced non-strategic, incoherent policy rhetoric in its uninterrupted pursuit of budgetary increases in foreign aid. Traditionally, the early foreign aid policy regime appears to have lacked mechanisms for consensus making either across the aid administration or between state and society. As a result, the aid regime continuously displayed policy behaviour that was externally reactive and rhetorical about aid expansion.

Regrettably, it is for future study to find further rigorous evidence to support the validity of the RS argument; this essay is, rather, confined to highlighting the relevance of the reactive state thesis in our understanding of South Korea's contemporary aid rhetoric.

\section{REFERENCES}

Alesina, Alberto and David Dollar. 2000. "Who Gives Foreign Aid to Whom and Why?" Journal of Economic Growth 5: 33-63.

Breuning, Marijke. 1995. "Words and Deeds: Foreign Assistance Rhetoric and Policy Behaviour in the Netherlands, Belgium, and the United Kingdom." International Studies Quarterly 39(2): 235-254.

Bulir, Ales and Javier Hamann. 2008. "Volatility of Development Aid: From the Frying Pan into the Fire?" World Development 36(10): 2045-2102.

Calder, Kent E. 1988. "Japanese Foreign Economic Policy Formation: Explaining the Reactive State." World Politics 40(4): 517-541.

Evans, Peter B. 1995. Embedded Autonomy: States and Industrial Transformation. Princeton, NJ: Princeton University Press.

Evans, Peter B. 2010. Chapter 2. "Constructing the 21th century developmental state: potentialities and pitfalls." In Constructing a Democratic Developmental State in South Africa: Potentials and Challenges edited by Omano Edi-gheji. Cape Town: HSRC Press. 
Hahm, Sung-Deuk and Christopher Plein. 1995. "Institutions and Technological Development in Korea: The Role of the Presidency." Comparative Politics 28(1): 55-76.

Hook, Steven. 1995. National Interest and Foreign Aid. Lynne Rienner Publishers. Hook, Steven, Schraeder, Peter and Bruce Taylor. 1998. Clarifying the Foreign Aid Puzzle: A Comparison of American, Japanese, French, and Swedish Aid Flows. World Politics 50(2): 294-323.

Herring, Ronald. 1999. "Embedded Particularism: India's Failed Developmental State." In The Developmental State edited by M. Woo-Cumings. Ithaca, NY: Cornell University Press.

Hook, Steven and Guang Zhang. 1998. “Japan's Aid Policy since the Cold War: Rhetoric and Reality." Asian Survey 38(11): 1051-1066.

Hwang, Suk-Man and Hyun-Chin Lim. 2003. "Restructuring Revisited: Flexible Korea and Rigid Japan.” Development and Society 32(2): 229-252.

Inoguchi, Takashi. 1989. "Four Japanese Scenarios for the Future." International Affairs 65(1): 15-28.

Inoguchi, Takashi and Purnendra Jain. 2011. Japanese Politics Today: From Karaoke to Kabuki Democracy. Palgrave Macmillan.

Johnson, Chalmers. 1982. MITI and the Japanese Miracle: The Growth of Industrial Policy: 1925-1975. Stanford University Press.

Johnson, Chalmers, 1999. "The Developmental State: Odyssey of a Concept." In The Developmental State edited by M. Woo-Cumings. Ithaca, NY: Cornell University Press.

Kalinowski, Thomas and Hyekyung Cho. 2012. "Korea's Search for a Global Role between Hard Economic Interests and Soft Power." European Journal of Development Research 24: 242-260.

Kangoye, Thierry. 2013. "Does Aid Unpredictability Weaken Governance? Evidence from Developing Countries." The Developing Economies 51(2): 121-144.

Katada, Saori N. 2002. "Japan's Two-Track Aid Approach: The Forces Behind Competing Triads." Asian Survey 42(2): 320-342.

Kim, Jiyoung. 2011. "Foreign Aid and Economic Development: The Success Story of South Korea." Pacific Focus 26(2): 260-286.

Kim, Sang-Tae and David Seddon. 2005. "ODA Policy and Practice: Japan and the Republic of Korea." In Japan's Foreign Aid: Old Continuities and New Directions edited by D. Arase. Abingdon, Oxon: Routledge.

Kohli, Atul. 2004. State-directed Development: Political Power and Industrialization in the Global Periphery. New York: Cambridge University Press.

Lensink, Robert and Oliver Morrissey. 2000. "Aid Instability as a Measure of Uncertainty and the Positive Impact of Aid on Growth." The Journal of Development Studies 36(3): 31-49.

Lim, Hyun-Chin. 1985. Dependent Development in Korea 1963-1979. Seoul Na- 
tional University Press.

Miyashita, Akitoshi. 1999. "Gaiatsu and Japan's Foreign Aid: Rethinking the Reactive-Proactive Debate.” International Studies Quarterly 43: 695-732.

Miyashita, Akitoshi and Yoichiro Sato, editors. 2001. Japanese Foreign Policy in Asia and the Pacific. Palgrave Macmillan.

Morgenthau, Hans. 1962. "A Political Theory of Foreign Aid." The American Political Science Review 55(2): 301-309.

OECD. 2015. Development Co-operation Report 2015: Making Partnerships Effective Coalition for Action. Development Co-operation Directorate (DCDDAC), the Organisation for Economic Co-operation and Development (OECD).

Orr, Robert M. 1990. The Emergence of Japan's Foreign Aid Power. Columbia University Press.

Potter, David and Hyo-Sook Kim, editors. 2012. Foreign Aid Competition in Northeast Asia. Kumarian Press Book.

Potter, David and Sudo Sueo. 2003. "Japanese Foreign Policy: No Longer Reactive?" Political Studies Review 1: 317-332.

Rix, Alan. 1990. “Japan's Foreign Aid Policy: A Capacity for Leadership?” Pacific Affairs 62 (4): 461-475.

Sato, Jin and Yasutami Shimomura, editors. 2012. The Rise of Asian Donors: Japan's Impact on the Emerging Donors. Routledge.

Söderberg, Marie. 2010. "Challenges or Complements for the West: Is there an 'Asian' Model of Aid Emerging?" In Challenging the Aid Paradigm: Western Currents and Asian Alternatives edited by J. S. Sörensen. Basingstoke: Palgrave Macmillan.

Woo, Jung-Eun. 1991. Race to the Swift: State and Finance in Korean Industrialization. Columbia University Press.

Woo-Cumings, Meredith. 1999. "Introduction: Chalmers Johnson and the Politics of Nationalism and Development." In The Developmental State edited by M. Woo-Cumings. Ithaca, NY: Cornell University Press.

World Bank. 1993. The East Asian Miracle: Economic Growth and Public Policy. Main Report: A World Bank Policy Research Report. New York: Oxford University Press.

Yasutomo, Dennis T. 1990. "Why Aid? Japan as an Aid Great Power." Pacific Affairs 62(4): 490-503. 


\section{ENDNOTES}

1 The Development Assistance Committee of the Organisation for Economic Co-operation and Development (OECD-DAC).

2 ODA/GNI indicates a ratio of gross national income to the volume of official development assistance.

3 Gaiatsu (外圧) means “external pressure” in the Japanese language.

4 Nawabari(なわばり) stands for individual areas of technical expertise and established professional concern (Calder 1988: 529).

51962 Ohira-Kim (J.P.) Memo was the outcomes of closed-door negotiations between the Ikeda cabinet and the Park regime in regard to compensation for the Republic of Korea under Japanese rule. This reparations deal, despite the furious nationalist sentiment against Japan in the South Korean society, allowed Seoul to channel foreign capital and technology to local businesses: Japanese aid came in grants (USD 0.3 billion), concessional loans (USD 0.2 billion), and commercial loans (USD 0.1 billion). The major beneficiaries were the Pohang Iron and Steel Company and other enterprises in the industrial sectors of railway, expressways, telephones, dams, shipping, and electricity, etc.

6 The United States Agency for International Development

${ }^{7}$ Non-aligned Movement (NAM) was a multilateral project among Third World countries, which pledged to hold a neutral position between the communist and capitalist blocs since the early 1960s. North Korea was a signatory country to the multilateral treaty, whereas South Korea was not.

8 MOFA's Standard Operating Procedures on Grant Aid was published in 1987.

9 In South Korea, the names and jurisdiction of ministries are constantly shifted at times of administrative reform or regime change. As of 2015, the Foreign Affairs Ministry was renamed the Ministry of Foreign Affairs (MOFA).

${ }^{10}$ As of 2015, the Finance Ministry was renamed the Ministry of Strategy and Finance (MOSF).

${ }^{11}$ In Japan, the Ministry of Finance and the Ministry of International Trade and Industry formed a cohesive developmental coalition with domestic businesses. 